\title{
Conditioning Sheep to Graze Duncecap Larkspur (Delphinium occidentale)
}

\author{
Michael H. Ralphs \\ Author is Rangeland Scientist, USDA/ARS Poisonous Plant Laboratory, Logan, UT 84341.
}

\begin{abstract}
Sheep are more resistant than cattle to larkspur poisoning and thus may be used as a biological tool to graze larkspur to reduce cattle poisoning. Sheep readily graze larkspur in its mature stages, but if they are to be an effective management tool, they must graze it in the early growth stages before cattle enter the allotment. The objective of this study was to determine if sheep could be positively conditioned to graze duncecap larkspur (Delphinium occidentale (S. Wats) S. Wats) early in its growth stages. Eighteen ewes were divided into 3 groups of 6 ewes each. During conditioning, group 1 was offered potted larkspur plants then were gavaged with glucose, the second group was exposed to larkspur plants together as a group (social facilitation), and the third group was an untreated control. In the preference test, the glucose group ate more duncecap larkspur than the social facilitation and control groups. The glucose and control groups were taken to duncecap larkspur-infested mountain rangeland to test the conditioning. In the field grazing trial, the glucose group consumed more larkspur than the control group, but it occurred later in the grazing trial when larkspur was in flower and after desirable forages had been consumed. High levels of diterpenoid alkaloids in larkspur and other alternative palatable forages may have caused ewes to reject larkspur at the beginning of the trial. The sheep were positively conditioned to graze larkspur, but the amount consumed and the timing of consumption was not sufficient to prevent potential cattle poisoning.
\end{abstract}

\section{Resumen}

Los ovinos son más resistentes que los bovinos a la intoxicación por "Larkspur", por lo que pueden ser usados como una herramienta biológica para apacentar el "Larkspur" y reducir la intoxicación del ganando bovino. Los ovinos son capaces de apacentar "Larkspur" en sus etapas maduras, pero si ellas van a ser una herramienta efectiva de manejo, ellos deben apacentar el "Larkspur" en las etapas iniciales de crecimiento, antes de que el ganado bovino entre al potero. El objetivo de este estudio fue determinar si los ovinos pudieran ser acondicionados positivamente para apacentar el "Duncecap larkspur" (Delphinium occidentale (S.Wats) S. Wats) en las etapas iniciales de crecimiento. Un grupo de 18 borregas se dividió en tres grupos de seis animales cada uno. Durante el acondicionamiento, al grupo 1 se le ofreció plantas de "Larkspur" en recipientes las cuales fueron adicionadas con glucosa, en el segundo grupo todos los animales fueron expuestos juntos a plantas de "Larkspur" (Facilitación social) y el tercer grupo fue el control sin tratamiento. En la prueba de preferencia, el grupo con glucosa comió más "Duncecap larkspur" que los grupos de facilitación social y testigo. Los grupos de glucosa y testigo se llevaron a un pastizal montano infestado con "Duncecap larkspur" para evaluar el acondicionamiento. En la prueba de apacentamiento en campo. El grupo con glucosa consumió más "Larkspur" que el grupo control, pero esto ocurrió al final de la prueba de apacentamiento cuando el "Larkspur" estaba en floración y después de que los forrajes deseables habían sido consumidos. Altos niveles de alcaloides diterpenoides presentes en el "Larkspur" y la presencia de otros forrajes de alta gustocidad pudo haber causado el rechazo del "Larkspur" por las borregas al inicio del ensayo. Los ovinos fueron acondicionados positivamente para apacentar el "Larkspur", pero la cantidad consumida y el tiempo de consumo no fue ron suficientes para prevenit un envenenamiento potencial del ganado bovino.

Key Words: positive conditioning, nutrient loading, poisonous plant, sheep grazing

\section{INTRODUCTION}

Larkspur (Delphinium spp.) poisoning of cattle is the largest poisonous plant problem on mountain rangelands in the western United States. Larkspur is relatively palatable and abundant on high mountain rangelands. Because of differences in receptor sites in the neuromuscular junction, sheep are more resistant to the toxic diterpenoid alkaloids than are cattle (Olsen 1978), and thus may be used as a biological tool to graze larkspur to reduce its availability and subsequent threat to cattle (Ralphs and Olsen 1992). Larkspur is considered good

Correspondence: Michael H. Ralphs, USDA/ARS Poisonous Plant Laboratory, $1150 \mathrm{E}$, 1400 N, Logan, UT 84341. Email: mralphs@cc.usu.edu.

Manuscript received 16 January 2005; manuscript accepted 7 July 2005. sheep forage. Sheep readily graze larkspur in its mature stages, but are reluctant to select larkspur voluntarily in the early growth stages (Ralphs et al. 1991). If sheep are to be an effective management tool, they must graze it in the early growth stages before cattle enter the grazing allotment.

One theory of diet selection states that animals learn which plants to eat or avoid based on postingestive consequences (Provenza 1995). Foods that replenish specific nutrients are preferred, whereas those that cause nausea or illness are avoided. Thus, animals can acquire preferences for less palatable foods that are paired with nutrients, such as glucose (Burritt and Provenza 1992; Ralphs et al. 1995), propionate (Villalba and Provenza 1996; Villalba and Provenza 1997a), starch (Villalba and Provenza 1997b), and nitrogen (Villalba and Provenza 1997c).

Social facilitation is another factor that might influence acceptance or preference for a food. Animals can be influenced 
Table 1. Standing crop ( \pm standard error) of duncecap larkspur plant parts and other forage classes at the beginning and end of the grazing trial near Oakley, Idaho.

\begin{tabular}{lccccc}
\hline & \multicolumn{2}{c}{ Conditioned group $(\mathrm{kg} / \mathrm{ha})$} & & \multicolumn{2}{c}{ Control group $(\mathrm{kg} / \mathrm{ha})$} \\
\cline { 2 - 3 } \cline { 5 - 6 } Forage class & Begin & End & & Begin & End \\
\hline Larkspur & $572 \pm 126$ & $470 \pm 174$ & & $460 \pm 91$ & $602 \pm 159$ \\
Other forbs & $460 \pm 72$ & $440 \pm 63$ & & $352 \pm 47$ & $200 \pm 48$ \\
Grass & $464 \pm 82$ & $268 \pm 47$ & & $484 \pm 47$ & $284 \pm 52$ \\
Total & $1496 \pm 123$ & $1178 \pm 176$ & & $1296 \pm 108$ & $1086 \pm 183$ \\
\hline
\end{tabular}

to eat new foods or increase consumption of familiar foods when companions are eating those foods (Tolman 1964).

The objective of this research was to determine if sheep could be positively conditioned to accept immature duncecap larkspur (Delphinium occidentale (S. Wats) S.Wats) by 1) pairing the taste of larkspur with supplemental energy as a positive feedback, or 2) inducing them to accept it through social facilitation.

\section{METHODS}

\section{Conditioning}

Eighteen mature ewes of mixed Suffolk-Finish breeding $(70 \mathrm{~kg}$ ) were used in this study. They had grazed on mountain rangeland but were naïve to duncecap larkspur. They were randomly allocated to 3 groups of 6 ewes each to receive 1 of the following treatments: 1) nutrient loading using glucose as an energy supplement to condition preference, 2) social facilitation to evaluate the social influence or peer pressure of companions in acquiring a preference, and 3) an untreated control. Animals were handled by methods approved by an Institutional Animal Care and Use Committee.

The conditioning trial lasted 6 days. Glucose was selected as the supplemental energy source because it conditioned preferences for straw pellets in a previous experiment (Ralphs et al. 1995). The dose of $100 \mathrm{~g}$ glucose $(0.572 \mathrm{Mcal})$ was dissolved in $2 \mathrm{~L}$ of tap water and gavaged using a stomach tube. This represented $20 \%$ of the ewes' daily net energy requirement for maintenance, and was midway between the low and high levels of glucose that conditioned preferences for straw (Ralphs et al. 1995). Ewes in the glucose group were placed in separate pens and were offered a single potted plant of duncecap larkspur in their feed trough for 30 minutes each morning. The plants had been excavated from the field study site the previous year and maintained in a greenhouse. The stems had elongated $(0.5 \mathrm{~m}$ in height) but were not yet in flower, and their foliar biomass ranged from 60 to $85 \mathrm{~g}$ fresh weight. Consumption was measured by difference by weighing plants in and out of the pen. Ewes in the social facilitation group were placed together in a pen and offered 6 duncecap larkspur plants within the pen in a group feeding situation for 30 minutes each day. The control group received no exposure to larkspur during the conditioning trial. The animals were fed a basal ration of alfalfa pellets $(2 \% \mathrm{BW})$ at noon each day. The amount of feed was not adjusted for the energy content of glucose in group 1 .

\section{Preference Test}

Preference was tested for 4 days. All ewes were placed in individual pens and larkspur was offered each morning. Two potted plants of duncecap larkspur were placed in their feed trough for 1 minute. Consumption was measured by weighing the plants in and out of the troughs. The amount of larkspur consumed was analyzed by repeated-measures mixed analysis of variance ANOVA comparing groups over days using a compound symmetry covariance structure. Following a significant $F$ test, means were separated by the PDmix 800 macro in SAS (Saxton 1998) using the Tukey adjustment. Individual ewes were considered experimental units to which the treatments were applied.

\section{Field Grazing Trial}

Ewes from the glucose and control groups were taken to mountain rangeland $45 \mathrm{~km}$ west of Oakley Idaho (lat $42^{\circ} 10^{\prime} 10^{\prime \prime} \mathrm{N}$, long $114^{\circ} 10^{\prime} 34^{\prime \prime} \mathrm{W}$ ) at $2500 \mathrm{~m}$ elevation for a field grazing trial that ran from 29 June to 24 July. Duncecap larkspur was the dominant species in swales within the mountain big sagebrush (Artemisia tridentata spp. vaseyana (Rydb) M. Boivin) vegetation zone. Other associated species included mountain brome (Bromus carinatus H. \& A.) slender wheatgrass (Elymus trachycaulus (Link) Gould ex Shinners), aster (Aster engelmannii (D.C. Eaton) Gray), and violet (Viola nuttallii Pursh). Four 0.5-ha pastures were fenced with temporary electric fence. Ewes from the glucose and control groups were divided into 2 replications of 3 sheep each and randomly assigned to pastures. Diets were quantified by a bite count technique (Lehner 1987). Each ewe was observed for 2-minute periods 3-7 times each day during active grazing periods. The number of bites of each species was recorded and aggregated into the following forage classes: larkspur, other forbs, and grass. The percentage of bites of each forage class was analyzed by repeated-measures mixed ANOVA comparing treatment groups over weeks of the trial, using a heterogeneous firstorder autoregressive covariance structure. Means and standard errors (SEs) are presented in the text and figures.

\section{Standing Crop, Larkspur Utilization, and Alkaloid Levels}

Larkspur was in the bud elongation stage (flowering raceme elongation prior to flower emerging) at the beginning of the trial and matured to the full flower stage by the end of the trial. Its biomass likely increased during this time. Standing crop was sampled at the beginning and end of the field grazing trial. Two paced transects were located in each pasture and 10 quadrats $(1 \times 0.25 \mathrm{~m})$ were systematically located at 5-step intervals along each transect to cover the pasture uniformly. The species and forage classes were clipped, dried in a forced-air oven at $60^{\circ} \mathrm{C}$ for 48 hours, and weighed. Means and SEs of the forage classes are presented in Table 1.

Duncecap larkspur utilization was measured at the end of the study. Five paced transects were located in each pasture and the larkspur plant located nearest the toe at 5 step-intervals was selected ( 25 plants/pasture). We counted the number of stalks, leaves per stalk, and the number of flowering heads and leaves removed (empty petioles remaining) by the sheep. Percent of heads and leaves grazed were compared between treatment 


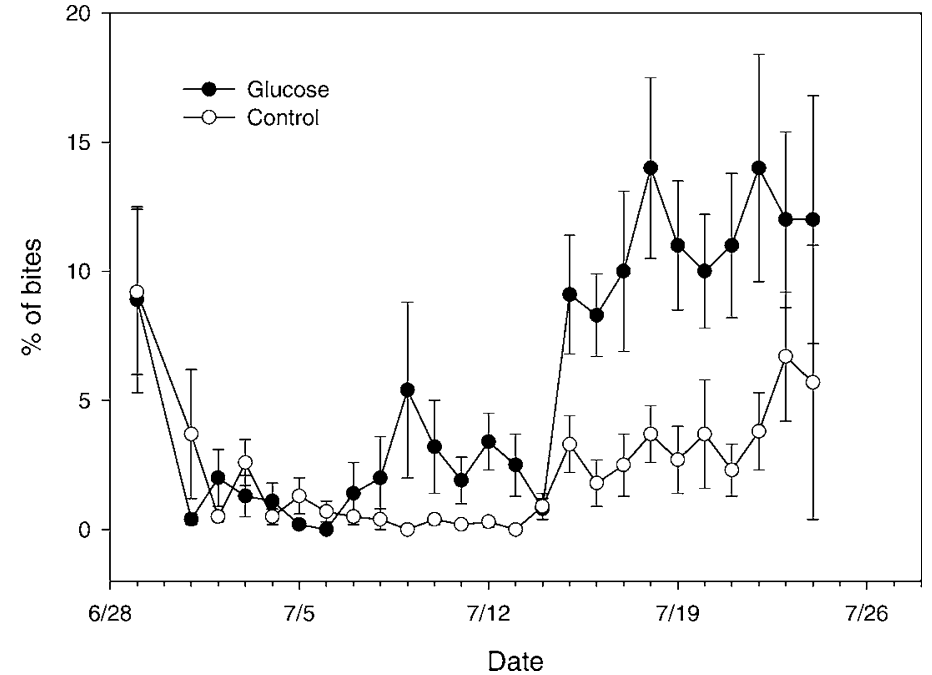

Figure 1. Intake of duncecap larkspur (\% of bites) by the positively conditioned group and control group during the field grazing trial at Oakley, Idaho. Error bars are standard errors.

groups by ANOVA. Individual plants were considered experimental units.

Toxic alkaloid concentration was measured in larkspur plants near the study site. Leaves and flowering heads were composited from 30 to 50 randomly selected plants at 2-week intervals throughout the growing season. Plant samples were air-dried in a forced air oven at $60^{\circ} \mathrm{C}$ for 48 hours, ground, extracted using acid/base partitioning, and the principal toxic alkaloids were quantified by high-performance liquid chromatography using columns packed with Spherisorb neural alumina (Phase Separations Inc, Norwalk, CT) and the carrier was aqueous isopropyl alcohol (Manners and Pfister 1993).

\section{RESULTS}

In the preference test, the glucose group consumed more larkspur than the social facilitation or control groups $\left(49 \pm 2.1 \mathrm{SE}\right.$, vs. $36 \pm 3.2 \mathrm{SE}$ and $25 \pm 2.2 \mathrm{~g} \mathrm{~min}^{-1} \mathrm{SE}$, respectively; $P=0.027$ ). There was little change in consumption during the 4-day preference test by the glucose and social facilitation groups, indicating the conditioned preferences were stable. However the control group increased larkspur consumption over the trial (from 11 to $33 \mathrm{~g} \mathrm{~min}^{-1}$ ), indicating a learned acceptance for it upon repeated exposure (group-byday interaction, $P=0.05$ ).

Because the glucose group acquired the greatest preference for duncecap larkspur in the conditioning phase, they were taken to the field and compared with the control group for their preference for larkspur. In the field grazing trial, the glucose group consumed more duncecap larkspur than the control group $(P=0.003)$. However, there was a group-by-time interaction $(P=0.03)$. Both groups started eating larkspur on the first day for about $9 \%$ of bites, then ceased for the middle part of the trial (Fig. 1). The glucose group increased larkspur consumption to a greater degree than the control group, consuming duncecap larkspur up to $15 \%$ of bites by the end of the trial.

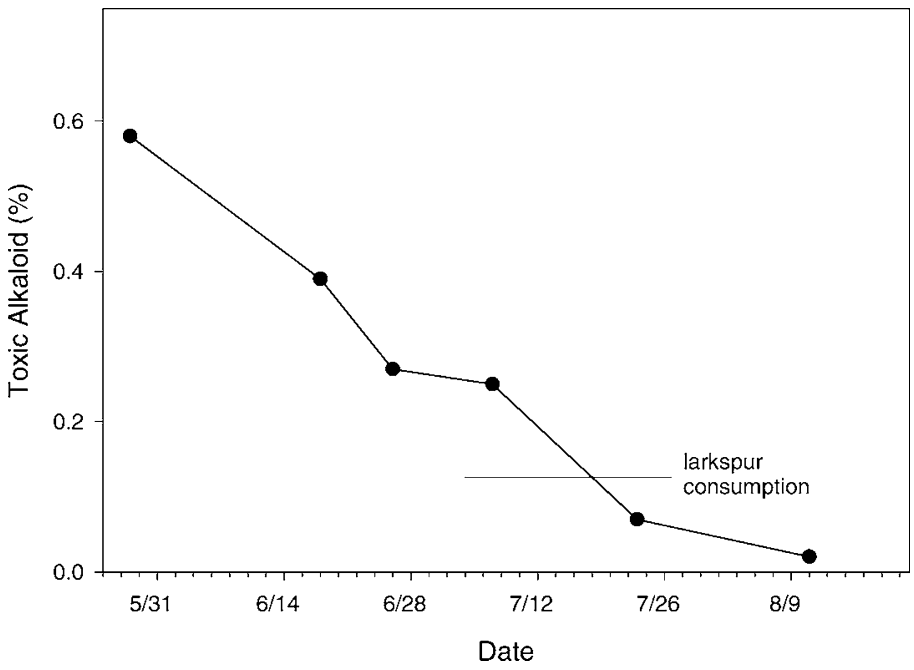

Figure 2. Concentration (\% of dry matter) of toxic alkaloids in duncecap larkspur over the growing season. Sheep entered the pastures on 29 June, but larkspur consumption began on 6 July, and increased through the end of the study on 24 July. Larkspur consumption reflects the period in which it was consumed by the ewes in this study.

The utilization study of individual plants at the end of the grazing trial showed the glucose group consumed more larkspur leaves than the control group $(6 \%$ vs. $1 \%$ of leaves counted; $P=0.006)$. However, there was no difference between groups in the percentage of larkspur heads grazed $(30 \%$ vs. $28 \%$, respectively). Standing crop of larkspur was not reduced by sheep grazing (Table 1 ).

Toxic diterpenoid alkaloid concentration of duncecap larkspur declined as the plants matured as the season progressed (Fig. 2). Toxic alkaloid concentration was low during the latter part of the grazing trial when ewes started consuming duncecap larkspur. Toxic alkaloid levels less than $0.3 \%$ pose low risk of poisoning (Pfister et al. 1997).

\section{DISCUSSION}

Ewes fed duncecap larkspur then gavaged with glucose increased the amount of larkspur consumed in the pen feeding trial. Although the alkaloid concentration in the potted plants was probably similar to that in the plants in the field grazing study (because they were of similar phenological growth stages), the lack of alternative choices in the pen forced consumption of duncecap larkspur and conditioned an acceptance for it. Other studies have conditioned preferences for unpalatable feeds using energy sources such as glucose (Burritt and Provenza 1992; Ralphs et al. 1995), propionate (Villalba and Provenza 1996; 1997a), starch (Villalba and Provenza 1997b; Ralphs and Wiedmeier 2004), and supplemental nitrogen (Villalba and Provenza 1997c). In a previous study, Ralphs et al. (1995) reported that the glucose treatment increased rumen microbial mass, which increased volatile fatty acid (VFA) concentration in the rumen. Once absorbed, VFAs enter the liver, which is the primary organ responsible for sensing caloric density (Tordoff and Friedman 1986). The liver, along with gastrointestinal enzymes (Grovum 1988), may send 
signals of caloric density along visceral nerves, which converge with gustatory and olfactory nerves in the brain stem to form preferences for that food (Provenza 1995).

The enhanced consumption of larkspur by the glucose group in the pen did not condition a preference for duncecap larkspur at the beginning of the field grazing trial. Both groups started eating the larkspur the first day of the field trial, then ceased. High concentrations of alkaloids and alternative feed choices apparently reduced the relative palatability for duncecap larkspur at the beginning of the grazing trial. Larkspur is very nutritious, with crude protein declining from $26 \%$ at the beginning of growth to $15 \%$ in the pod stage, and neutral detergent fiber of leaves ranging between 12 and $20 \%$ throughout the growing season (Pfister et al. 1988). However, its high nutritive value was apparently offset by the high levels of alkaloids in its early growth stages.

The positively conditioned group of ewes in our study did increase consumption of larkspur toward the end of the grazing study as the concentration of toxic alkaloids declined (Fig. 2). Sheep have the ability to discriminate between low and high alkaloid levels in larkspur species (Pfister et al. 1996). The high alkaloid levels in early growth may be responsible for its rejection at that time (Ralphs et al. 1991), but once the alkaloid concentration declined, the positively conditioned sheep were able to express their relative preference for larkspur.

Increasing grazing pressure as the trial progressed, and maturity of associated species, may also have influenced larkspur consumption patterns. Immature grass and other forbs were abundant at the beginning of the trial. As the more palatable species or plant parts were removed by grazing, or matured over the grazing trial, the ewes accepted increasing amounts of larkspur.

This experiment was one of the first field tests of the concept of nutrient loading to positively condition animals to graze a target plant. It was only partly successful. Nutrient loading did increase consumption of duncecap larkspur in the single-choice pen trial. However, when the ewes were taken to the field in a complex plant community, the preference for larkspur was not maintained. The complex interactions of abundant and nutritious grasses and forbs that were available, and the high levels of alkaloids in duncecap larkspur, overcame the positive conditioning for larkspur at the beginning of the field trial. Toward the end of the grazing trial, the declining concentration of alkaloids in duncecap larkspur and the declining availability or maturity of the more palatable plants likely contributed to increased larkspur consumption. The positively conditioned group did consume more larkspur than the control group toward the end of the grazing trial, even though nutrient loading to condition preference ceased 35 days earlier.

\section{MANAGEMENT IMPLICATIONS}

Nutrient loading increased acceptance of duncecap larkspur in the pen and in the field after larkspur matured to the flower growth stage. However, the small amount consumed was not likely to reduce the larkspur biomass available to cattle, and thus reduce the risk of poisoning. Sheep grazed about $30 \%$ of the flowering heads, but the larkspur standing biomass declined very little. Furthermore, larkspur consumption occurred in the latter part of the trial when larkspur was in flower, and after the more palatable forages were depleted. The objective of this study was to condition sheep to graze larkspur preferentially early in the season to reduce its availability and subsequent risk of poisoning to cattle grazing later that season. This objective was not accomplished. It is unlikely that positive conditioning will overcome the high level of alkaloids in duncecap larkspur in its early growth stage when alternative forages are available.

\section{LITERATURE CITED}

Burritt, E. H., and F. D. Provenza. 1992. Lambs preference for non-nutritive flavors paired with glucose. Journal of Animal Science 70:1133-1136.

Grovum, W. L. 1988. Appetite, palatability and control of feed intake. In: D. C. Church [ED.]. The ruminant animal. Englewood Cliffs, NJ: Prentice-Hall. p 202-216.

LeHNER, P. N. 1987. Design and execution of animal behavior research: an overview. Journal of Animal Science 65:1231-1219.

Manners, G. D., And J. A. Pfister. 1993. Normal phase liquid chromatographic analysis of toxic norditerpenoid alkaloids. Phytochemical Analysis 4:14-18.

OLSEN, J. D. 1978. Tall larkspur poisoning in cattle and sheep. Journal of the American Veterinary Medical Association 173:76.

Pfister, J. A., D. R. Gardner, and K. W. Price. 1997. Grazing risk on tall larkspurinfested ranges. Rangelands 5:12-15.

Pfister, J. A., G. D. Manners, D. R, Gardner, K. W. Price, and M. H. Ralphs. 1996. Influence of alkaloid concentration on acceptability of tall larkspur (Delphinium spp.) to cattle and sheep. Journal of Chemical Ecology 22:1127-1168.

Pfister, J. A., G. D. Manners, M. H. Ralphs, Z. X. Hong, and M. A. Lane. 1988. Effects of phenology, site, and rumen fill on tall larkspur consumption by cattle. Journal of Range Management 41:509-514.

Provenza, F. D. 1995. Postingestive feedback as an elementary determinant of food preference and intake in ruminants. Journal of Range Management 48:2-17.

Ralphs, M. H., J. E. Bowns, and G. D. Manners. 1991. Utilization of larkspur by sheep. Journal of Range Management 44:619-622.

RalPhs, M. H., AND J. D. OLSEN. 1992. Prior grazing by sheep reduces waxy larkspur consumption by cattle. Journal of Range Management 45:136-139.

Ralphs, M. H., F. D. Provenza, R. D. Wiedmeier, and F. B. Bunderson. 1995. Effects of energy source and food flavor on conditioned preferences in sheep. Journal of Animal Science 73:1651-1657.

Ralphs, M. H., and R. D. Wiedmeler. 2004. Conditioning cattle to graze broom snakeweed (Gutierrezia sarothrae). Journal of Animal Science 82:3100-3106.

SAXton, A. M. 1998. A macro for converting mean separation output to letter groupings in Proc Mixed. Proceedings 23rd SAS Users Group International. Cary, NC: SAS Institute. p 1243-1246.

Tolman, C. W. 1964. Social facilitation of feeding behavior in domestic chicks. Animal Behavior 12:245-251.

Tordoff, M. G., And M. I. Friedman. 1986. Hepatic portal glucose infusions decrease food intake and increase food preference. American Journal of Physiology 251:192.

Villalba, J. J., and F. D. Provenza. 1996. Preference for flavored wheat straw by lambs conditioned with intraruminal administrations of sodium propionate. Journal of Animal Science 74:2362-2368.

Villalba, J. J., And F. D. Provenza. 1997a. Preference for flavored wheat straw by lambs conditioned with intraruminal infusions of acetate and propionate. Journal of Animal Science 75:2905-2914.

Villalba, J. J., and F. D. Provenza. 1997b. Preference for wheat straw by lambs conditioned with intraruminal infusions of starch. British Journal of Nutrition 77:287-297.

Villalba, J. J., and F. D. Provenza 1997c. Preference for flavored foods by lambs conditioned with intraruminal administration of nitrogen. British Journal of Nutrition 78:545-561. 